\title{
Applicability and critical analysis of the use of eponyms in Health Sciences
}

\author{
BATigália, F. ${ }^{*}$, BOER, N. P. ${ }^{2}$, MARCATTO, G. ${ }^{2}$, MARCATTO, G. ${ }^{2}$ and \\ BOER, A. L. R. ${ }^{2}$
${ }^{1}$ Faculdade de Medicina de São José do Rio Preto - FAMERP, CEP 15090-000, São José do Rio Preto, SP, Brasil
${ }^{2}$ Universidade Camilo Castelo Branco - UNICASTELO, CEP 15600-000, Fernandópolis, SP, Brasil \\ *E-mail: batigalia@famerp.br
}

\begin{abstract}
Introduction: Specific words have been adopted to designate the several structures in Human Anatomy. However, the same structure has different names, usually derived from proper names (or Eponyms), which is still reflected in conceptual errors that complicate the Teaching and Learning of Anatomy in Multidisciplinary, Transdisciplinarity and Metadisciplinarity approaches. Within the current importance of the generalist, critical and humanistic background of the professional, the multiplicity of names of scientists and researchers attributed to anatomical structures has created real difficulties during the preparation, writing and reading of scientific papers, including the communication between Researchers and Professors. Objective: The aim of this study was to critically analyze the use of eponyms in Health Sciences, as well as compiling the eleven mains terms in which the same eponym has been used to identify at least two different structures. Results: Eponyms are not representatives of the first anatomists to describe structures or indicate some topographic, morphological or functional aspects associated with parts of the Human Body, and so must be replaced with a location, descriptive or etiological terminology that facilitates the structural understanding. Conclusion: Because of its clinical importance, eponyms will not completely disappear, but due to discrepancies and secondary confusions to its use, there have been many suggestions and impositions of anatomical societies to minimize their use.
\end{abstract}

Keywords: anatomy, morphology, eponym, health sciences, education, learning.

\section{Introduction}

The word nomenclature originates from the Latin [nomen (name), plural nomina and calare (call)]. Nomenclature or anatomical terminology is the set of terms used to indicate and describe the parts of the body. The human anatomical terminology is based on technical language in Anatomy, in Medicine and in other sciences related to the structure of man. It is the official list of international terms, also written in Latin, which designate the structures of the human body (FREITAS, 2004).

Thus, in the field of Biology and Medicine, it has been common to connect the name of the discoverers to the structure which are known as eponyms, a term of Greek origin (epónymo): adjective that gives or lends its name to something, the name of a disease, structure, method or operation, generally derived from the name of the person who has discovered or those who initially described them, for instance, a tendon (Achilles heel = calcaneal tendon), a ligament (Poupart ligament $=$ inguinal ligament $)$ or any other organ (fallopian tube = oviduct) (FERNANDES, 1999; REY, 1999; BEZERRA and BEZERRA, 2000).

After the sixteenth century, anatomical terms have arisen to describe the various structures. However, the same structures had different denominations, which came to cause great confusion reflected in occasionally conceptual errors. In the late nineteenth century, there were 50,000 names for approximately 5,000 human body formations (GARDNER,
GRAY and O'RAHILLY, 1988; BEZERRA and BEZERRA, 2000; SOCIEDADE..., 2001; FREITAS, 2004).

This disparity of terms to name the parts of the body, made a group of anatomists led by renowned German morphologists, which included experts in macroscopic structures, embryologists and histologists, prepare a list of names to establish a standard, official and worldwide vocabulary for all health sciences. The list, which was published in 1895, became known as the Basle Nomina Anatomica (BNA) or Basle Anatomical Nomenclature. In fact, a review of modern anatomical terminology had its beginning in Leipzig, German, in 1887 and continued in the UK in 1894 (GARDNER, GRAY and O'RAHILLY, 1988; DIDIO, 1998; BEZERRA and BEZERRA, 2000; PIATTO, BATIGÁLIA and NEVES, 2000, SOCIEDADE..., 2001; FREITAS, 2004).

The Basle Nomina Anatomica was published in Latin in 1895, after its unanimous approval at the IX Congress of Anatomische Gesellschaft (German Anatomical Society), held in Basel, Switzerland, on April 19, 1895. Unfortunately, it was not universally adopted, because it was only used by German, Italian, American and Latin American anatomists (BEAU, 1955; PIATTO, BATIGÁLIA and NEVES, 2000; SOCIEDADE..., 2001). This first international effort sought to provide a basis for universal agreement for the use of terms related to the human body for Anatomy and other Health Sciences (DIDIO, 1998; SOCIEDADE..., 2001; FREITAS, 2004). 
This proposal intented to adopt the same terminology and it would eliminate national differences that caused great confusion because the same structure was known by several names. Other discrepancies used the name of one or more scientists to honor those who made the first description of a certain structure, those who drew attention to it, and also those who demonstrated its significance or interpreted it correctly (DIDIO, 1998; PIATTO, BATIGÁLIA and NEVES, 2000; SOCIEDADE..., 2001).

As a result, some eponyms were kept due to its important use, which has generated much discussion, since different eponyms may characterize the same structure or the same eponyms characterize different structures (FREITAS, 2004). Thus, eponyms still have been widely used in the communication among Health Professionals, which causes confusion among structures or even lack of identification (BEZERRA and BEZERRA, 2000; PIATTO, BATIGÁLIA and NEVES, 2000).

\section{Materials and Methods}

We performed comprehensive and updated review of the scientific literature on Health Sciences, prioritizing scientific papers related to the proposed theme, available in the library of the University of São Paulo and Online Databases such as the CAPES Journal Portal, SCIELO, BIREME, MEDLINE, LILACS, and the collection of books in the library of the Department of Anatomy of UNICASTELO. In order to obtain references (SALVADOR, 1986; GIL, 1991), the descriptor "Eponyms and Anatomy," "Eponyms and Methodology", "Eponyms and Morphology" and "Eponyms and Health Sciences" were used, and their terms were cataloged and listed according to the etymological property of the same eponym since it would characterize at least two different structures.

\section{Results}

Table 1 shows the list of eponyms and the correspondent structures.

\section{Discussion}

Medical terms bring in their own constituents (prefixes, suffixes and radicals) semantic "parts", which together provide the very definition of the referent (SILVEIRA and BARROS, 2005). Eponyms have been widely used in Health Sciences from the discovery of the Scientific Method in Human Anatomy, due to the merit they express to one or more researchers who admittedly devoted much of their lives to Anatomical Research. However, in most cases, eponyms are not representative of the first anatomists to describe their structures, considering that Poupart, for example, was not the first to note the existence of inguinal ligament (FERNANDES, 1999; REY, 1999; BEZERRA and BEZERRA, 2000; PIATTO, BATIGÁLIA and NEVES, 2000). Moreover, eponyms do not indicate any topographical, morphological or functional aspect associated with parts of the Human Body (PIATTO, BATIGÁLIA and NEVES, 2000; SILVEIRA and BARROS, 2005).

Thus, the primary function of medical academics, associations of anatomists and international systems of nomenclature has been to systematically guide the non-breeding and non-use of eponyms, and replace them with alocation, descriptive or etiological terminology that facilitates structural understanding (PIATTO, BATIGÁLIA and NEVES, 2000; BEZERRA and BEZERRA, 2000; SILVEIRA and BARROS, 2005).

The Anatomical Terminology, like any living language, is under modifications, additions and deletions. The suggestions and justifications for changes should be directed to the Federative Committee on Anatomical Terminology (IFFA), which evaluates, vote to accept them and submit for final approval to the General Assembly of the International Federation of Association of Anatomists (PIATTO, BATIGÁLIA and NEVES, 2000; SILVEIRA and BARROS, 2005).

Although medical language should strive for objectivity and clarity, some eponyms are so comprehensive that the name of the discoverer has become a noun (e.g. roentgen, Roentgen WK, mendelism, Mendel GJ, Down Syndrome, Down JLH (PIATTO, BATIGÁLIA and NEVES, 2000). Moreover, it is unacceptable that an eponym may designate different structures (Table 1), which causes ambiguity interpretations and conceptual errors when describing complex structures, which greatly complicate communication between Researchers and Professors (BEZERRA and BEZERRA, 2000; FREITAS, 2004).

Table 1. List of the same eponym to identify at least two different structures $(n=11)$.

\begin{tabular}{ll}
\hline Boyden Sphincter & $\begin{array}{l}\text { Upper Sphincter muscle or lower sphincter muscle or sphincter muscle of hepatopancreatic ampulla } \\
\text { or sphincter muscle of bile duct or upper and lower sphincter muscle of sphincter muscle of bile } \\
\text { duct, sphincter muscle of hepatopancreatic ampulla and sphincter muscle of pancreatic duct }\end{array}$ \\
\hline Fascia of Colles & $\begin{array}{l}\text { Dartos tunic of the scrotum or subcutaneous tissue of penis or membranous layer (subcutaneous } \\
\text { tissue of perineum) }\end{array}$ \\
\hline Foramen of Morgagni & $\begin{array}{l}\text { Foramina nervosa of tympanic lamela of bone spiral lamina of cochlea (foramen to the posterior } \\
\text { tympanic nerve) or singular Foramen }\end{array}$ \\
\hline Arnold's Ganglion & Ganglion of upper cervical cardiac nerve or optic ganglion or carotid Glomus \\
\hline Luschka's Glands & Pharyngeal tonsil or coccygeal gland or mucous glands of gallbladder \\
\hline Arantius Ligament & Arcuate ligament of diaphragm or arcuate pubic ligament or arteriosus ligament \\
\hline Retzius Ligament & $\begin{array}{l}\text { Fundiform ligament of penis or fundiform ligament of clitoris or prostate-pelvic ligament or } \\
\text { deep insertion of the extensor retinaculum in the sinus tarsi }\end{array}$ \\
\hline Müller's Muscle & Circular fibers of ciliary muscle or orbital muscle or tarsal muscle of upper eyelid \\
\hline Santorini's Muscle & $\begin{array}{l}\text { Procerus muscle or risorius muscle or muscle of terminal notch (tragic muscle) or levator muscle } \\
\text { of upper lip or salpingopharyngeal muscle }\end{array}$ \\
\hline Bechterew's Nucleus & Rostral vestibular nucleus o rrostral superior vestibular nucleus or subhipoglossal \\
\hline Stilling's Nucleus & Fastigial nucleus or red nucleus or thoracic nucleus (thoracic spine) \\
\hline
\end{tabular}


Currently, the proposed solution (after analysis over the past decades) has been advocating that every society should have only one anatomical term for a structure; and it is also necessary that the terms should be short, descriptive and didactic, with Latin terminology and its corresponding translation into the language considered, and that eponyms are not isolated used (BEAU 1955; BEZERRA and BEZERRA, 2000; SILVEIRA and BARROS, 2005).

\section{Conclusions}

Eponyms are not representative of the first anatomists to describe their structures or indicate some topographic, morphological or functional aspect associated with parts of the Human Body, and so must be replaced with a location, descriptive or etiological terminology that facilitates the structural understanding. Because of its clinical importance, eponyms will not completely disappear, but due to discrepancies and confusion secondary to its use, there have been many suggestions and imperatives of anatomical societies to minimize their use.

\section{References}

BEAU, A. Nomina anatomica. Revises par lê Comitê International de la Nomenclatura Anatomique designe lors du Cinquiéme Congrés Internationald'Anatomie réunie á Oxford en 1950. Londres et Colchester: Spottswoole Ballantyne et Cie. SARL, 1955. p. 197-203.

BEZERRA, AJC. and BEZERRA, RFA. Epônimos de uso corrente em anatomia humana: um glossário para educadores físicos. Revista Brasileira de Ciência e Movimento, 2000, vol. 8, n. 3, p. 47-51.
DIDIO, LJA. Tratado de anatomia aplicada. São Paulo: Póluss Editorial, 1998.

FERNANDES, GM. Eponimia e etimologia. São Paulo: Plêide, 1999. p. $15-131$.

FREITAS, V. Anatomia: conceitos e fundamentos. Porto Alegre: Artmed, 2004. p. 27-32, 212-225.

GARDNER, E., GRAY, DJ. and O'RAHILLY, R. Anatomia. 4th ed. Rio de Janeiro: Guanabara Koogan, 1988.

GIL, AC. Como elaborar projetos de pesquisa. 3rd ed. São Paulo: Atlas, 1991.

PIATTO, VB.; BATIGÁLIA, F.; NEVES, AP. Terminologia médica e o uso de epônimos. HB Científica, 2000, vol. 7, n. 3, p. 183-188.

REY, L. Dicionário de termos técnicos de medicina e saúde. Rio de Janeiro: Guanabara Koogan, 1999. p. 276.

SALVADOR, AD. Métodos e técnicas de pesquisa bibliográficas. 11 th ed. Porto Alegre: Sulina, 1986.

SILVEIRA, FA. and BARROS, LA. Os termos eponímicos na terminologia da dermatologia. Estudos Lingüísticos, 2005, vol. xxxiv, p. 1134-1139.

SOCIEDADE BRASILEIRA DE ANATOMIA Terminologia anatômica. São Paulo: Manole, 2001. 